O outro fator - competitividade - necessário ao exportador (oferecimento de garantias de concorrência e execução - BID e performance bond), tem normas bem-definidas e as condições brasileiras são normalmente aceitas internacionalmente, mesmo que exista algum tipo de cláusula recusável, pois os seguradores brasileiros geralmente adaptam as condições, de tal maneira que os países admitem os novos termos sem nenhuma dificuldade. $\mathrm{O}$ apoio do seguro, entretanto, não se restringe a esses ramos. Operar em mercados novos com diversificação legislativa e geográfica implica novos riscos para os quais o exportador tem que estar preparado sob pena de comprometer seu investimento. Neste campo, aliás, o mercado brasileiro evoluiu bastante, podendo atender ao exportador na proteção dos seus riscos físicos, pessoais e de responsabilidade. No ramo da engenharia, por exemplo, podem ser cobertos fenômenos de força maior, como inundações, terremotos, etc. E as condições brasileiras são bastante flexíveis e adaptáveis às necessidades do exportador. Convém observar, entretanto, que o Brasil, através do Banco do Brasil, não vem exigindo, nos contratos de financiamento, seguro por segurado- ra brasileira, como o fazem, de seu lado, para proteger o segurador nacional, os países desenvolvidos, de que é exemplo a França: a hidrelétrica de Tucuruí, financiada por aquele país, teve os seguros colocados obrigatoriamente na França, em detrimento do segurador brasileiro. Um caso positivo de minha experiência na África: O Banco do Brasil financiou $80 \%$ de uma estrada, mas sob exigência contratual que a obra fosse segurada, por seguradora brasileira ou de primeiro nível daquela região.

Daí, as seguintes sugestões ora elevadas à consideração dos responsáveis pela política de seguros à exportação neste país: regulamentação da Brascex, que colocará à disposição do exportador uma empresa especializada em seguros de crédito à exportação, aliviando-o das dificuldades hoje existentes, desde que os riscos comerciais sejam emitidos por várias companhias privadas e os riscos políticos pelo Instituto de Resseguros do Brasil, tornando-se antieconômico; em caso de sinistro, acionar o importador inadimplente; norma operacional do Banco do Brasil consistente em obrigar a contratação de seguros em seguradoras brasileiras sempre que financiar projetos no exterior.

\title{
Riscos: responsabilidade, natureza e extensão
}

Mário Palmeira Ramos da Costa, advogado do Instituto de Resseguros do Brasil

Os riscos não são do segurador; este apenas cobre os riscos: os riscos são do exportador. De acordo com a lei brasileira, todo seguro de bens e servicos produzidos no Brasil tem que ser realizado no Brasil - essa a política do Instituto de Resseguros do Brasil, desde sua instituição em 1939. Mas o exportador precisa apresentar a sua necessidade de coberturas ao segurador, para que este a encaminhe a quem de direito, porquanto o contrato de seguro no Brasil é estabelecido pelo poder público através da Superintendência de Seguros Privados - Susep, órgão que estabelece o tipo de cobertura e as condições em que irá ser concedida.

Os riscos são vários; nem todos, porém, concernem a seguro, como o caso dos juros, que é de natureza eminentemente financeira. Ehá modalidades novas que reclamam coberturas novas: energia nuclear, poluição e outros que vão surgindo com o desenvolvimento econômico e tecnológico, que o

\section{Mário Palmeira Ramos da Costa}

seguro forçosamente reflete. Em qualquer caso, entretanto, é o segurado que deve procurar o segurador, assim como é o doente que deve procurar o médico.

Quanto ao seguro de crédito à exportação lque surgiu a partir da Segunda Guerra Mundial como forma de facilitar a exportação e vencer a concorrência, garantindo o crédito que o exportador fazia ao importador), nasceu no Brasil com a Lei . $^{\circ} 4.678$, de 1965 , regulamentada pelo Decreto n. 57.286 , também de 1965, vigentes até hoje. Cobre vários riscos: inadimplência contratual; prejuízos de negócios não-concluídos, embora adotados os empreendimentos necessários (por exemplo, desistência, pelo comprador de fabricação iniciada); má instrução do cadastro do importador (registram-se nesse sentido vários sinistros, inclusive, entre nós, e ajuizados, dada a situação de pré-insolvência do exportador já ao tempo do fornecimento do crédito e do segurol; 
desinteresse do exportador no cumprimento do contrato, em virtude da elevação do preço do produto que ele vai fornecer, já maior na praça; cobrança de sinistros, hipótese em que a insolvência se resolve no foro do domicílio do devedor, demandando a contratação de advogado local; e, finalmente, riscos quanto a defeitos de fabricação suscetíveis de cau- sar danos a terceiros (seguro de responsabilidade civil do produto, modalidade existente no Brasil mas quase não-utilizada pelo exportador), em que, na fase judicial, a ação não é movida diretamente contra o exportador, mas, sim contra o vendedor, pelo consumidor prejudicado, e pelo importador, por via regressiva, afinal, contra o exportador.

\section{Garantias do crédito à exportação. Normas internacionais}

George Rodrigues de Siqueira, assessor jurídico da Diretoria de Operações Cambiais do

Banco do Brasil S/A.

O comércio internacional não tem, por hipótese, fronteiras nem barreiras e está regulado por um conjunto de normas chamado a nova lex mercatória, que se apresenta sob quatro pilares fundamentais: os usos profissionais; os contratos tipo; as regulações ditadas pelo assento de cada profissão ou suas associações representativas; e a jurisprudência
George Rodrigues de Siqueira

arbitral. Mais recentemente surgiu um instrumento que procura estabelecer normas para as garantias internacionais. É a Publicação n. 325 da Câmara de Comércio Internacional, elaborada longamente por técnicos da Organização das Nações Unidas, que agiliza os negócios e os termos da garantia na área bancária.

\section{O risco de um Estado estrangeiro nas transações externas}

Eduardo Grebler, chefe da Assessoria Juridica da Construtora Mendes Júnior

A sistemática brasileira de crédito à exportação adota por princípio a linha de crédito ao vendedor - suply credits - , fazendo incidir sobre o exportador o risco da eventual inadimplência do importador estrangeiro.

A sistemática nada de grave apresenta intrinsecamente, exceto na hipótese das exportações de serviços, onde o exportador estrangeiro é na maioria ou totalidade das vezes um Estado ou pessoa ju-
Eduardo Grebler

rídica estatal. Nesses casos, quando há envolvimento de governo a governo, far-se-ia aconselhável a aplicação do sistema buys credit, não muito praticado entre nós.

A conseqüência principal desse estado de coisas é que o exportador brasileiro tem sido forçado a absorver o risco de um Estado estrangeiro, com acentuada desproporção de forças. 